\title{
Optimization of the Cultivation Conditions of Indigenous Wild Yeasts and Evaluation of their Leavening Capacity
}

\author{
Elsa Beyene Gebreslassie ${ }^{1}$, Anteneh T. Tefera², Diriba Muleta ${ }^{2}$, \\ Solomon K. Fantaye ${ }^{3}$, Gary M. Wessel ${ }^{4}$
}

\begin{abstract}
${ }^{1}$ Department of Microbial, Cellular and Molecular Biology, Addis Ababa University, King Goerge VI Street, P.O.Box 1176, Addis Ababa, Ethiopia

${ }^{2}$ Institute of Biotechnology, Addis Ababa University, King Goerge VI Street, P.O.Box 1176, Addis Ababa, Ethiopia;

${ }^{3}$ School of Biochemical Engineering, Addis Ababa Institute of Technology, King Goerge VI Street, P.O.Box 385, Addis Ababa, Ethiopia

${ }^{4}$ Department of Molecular and Cellular Biology and Biochemistry, Brown University, 185 Meeting Street, Providence RI 02912 USA
\end{abstract}

\begin{abstract}
Ethiopia has a high demand for baker's yeast in the bread and beverage industries. Unfortunately, Ethiopia has no producing plant for baker's yeast and instead relies on costly imports. The objective of this work was to identify the most productive and useful indigenous baker's yeasts isolated from local fermented foods and drinks, honey and Molasses using leavening ability as the major metric. Six of the test isolates produced a maximum cell mass at $30^{\circ} \mathrm{C}, \mathrm{pH}$ of 5.5 and 48 hours of incubation. Isolate AAUTf1 did not produce hydrogen sulfide, while isolates AAUTf5, AAUTj15 and AAUSh17 produced low levels of this chemical, and isolates AAUM120 and AAUWt21 produced high levels of hydrogen sulfide, neglecting their utility in baking. The leavening performance of isolates AAUTf1 (Candida humilis) and AAUTf5 (Kazachstania bulderi) had the highest dough volume of 131 $\mathrm{cm}^{3}$ and $128 \mathrm{~cm}^{3}$ respectively in $120 \mathrm{~min}$. Isolates AAUSh17 (Saccharomyces cerevisiae) and AAUTj15 (Saccharomyces cerevisiae) raised the dough volume of $127 \mathrm{~cm}^{3}$ and $125 \mathrm{~cm}^{3}$ respectively, at 60 min compared to commercial yeast $\left(117 \mathrm{~cm}^{3}\right.$ in $\left.90 \mathrm{~min}\right)$. The study also revealed that mixed cultures of indigenous yeasts had better leavening capacity than single cultures. The co- inoculated cultures of AAUTf1 + AAUTf5 + AAUTj15, AAUTf5 + AAUTj15, and AAUTf1 + AAUTj15 + AAUSh17 reached $143 \mathrm{~cm}^{3}$ at $90 \mathrm{~min}, 141 \mathrm{~cm}^{3}$ and $140 \mathrm{~cm}^{3}$ both at $60 \mathrm{~min}$, respectively. Thus, the indigenous isolates are candidates for optimizing utilization of yeast for fast promotion and utilization in the bakery industries.
\end{abstract}

Keywords: Dough Fermentation, Indigenous Yeasts, Leavening Activity, Mixed Culture, Single Culture

\section{Introduction}

The world population is growing and is expected to reach 9 billion people by the middle of this century (Jensen et al., 2015). One of the consequences of this increment in population is a higher consumption and a larger demand for processed food such as bread (Godfray et al., 2010). The greater demand for bread as a staple food for human consumption has led to the development and expansion of the baker's yeast industry (Zaky and Nasr, 2011).

Bread is a major nutritional component of humans and bread making is one of the oldest processes worldwide, known and practiced for thousands of years (Plessas et al., 2005). Yeasts are the major microorganism involved in bread making with key role of leavening bread dough.
Leavening is the metabolic process whereby yeast converts the carbohydrates in the dough to carbon dioxide gas that expands the dough prior to baking (Donalies et al., 2008; Edwards, 2007).

Baker's yeast (Saccharomyces cerevisiae) is the common name for the yeast commonly used as a leavening agent in baking bread and other bakery products, where it converts the fermentable sugars present in the dough into carbon dioxide and ethanol (Hamelman, 2004). The fermentative activity of baker's yeast is essential not only for the rising action of the dough by a production of carbon dioxide but also in a production of the wide range of aromatic compounds identified in bread (Birch et al., 2013).

Baked foods are widely consumed in Ethiopia and play an important role in the local economy

This article is published under the terms of the Creative Commons Attribution License 4.0 Author(s) retain the copyright of this article. Publication rights with Alkhaer Publications. Published at: http://www.ijsciences.com/pub/issue/2019-06/

DOI: 10.18483/ijSci.2043; Online ISSN: 2305-3925; Print ISSN: 2410-4477 
(Ashenafi, 2006). The bakery sector is constantly growing in Ethiopia due to an increasing demand for bread (particularly commercially prepared bread), constant growth in income, population, urbanization, and due to the shift from traditional consumption habits to fast food. Moreover, a number of alcohol and beverage industries (beer and wine) are active and these industries need tremendous amounts of yeast. As a result, the use of commercial baker's yeast is increasing day to day in the country.

The supply of commercial yeast in Ethiopia is currently met by importation due to lack of baker's yeast producing plants in the country (Milkessa and Abate, 2014). The country spent 293,010,632 ETB $(14,650,531.6$ US \$) in 2016 (CSA 2016) for the imported baker's yeast. This vital and highly expensive import necessitates alternatives for national development since the raw materials (molasses and wild yeasts) essential to isolate industrial yeasts are locally available.

Many different substrates (fermented foods, fermented beverages, citrus juice, sugarcane juice, molasses and others) are available for the isolation of yeast species (Arias et al., 2002; Ceccato-Antonini et al., 2004; Ashenafi, 2006; Aslankoohi et al., 2016). However, the leavening capacity of wild yeasts isolated from these substrates (teff dough, wheat dough, shamita, tej, and molasses) needs proper investigation in order to develop commercial scale production.

Therefore, it is necessary to isolate and develop superior performing baker's yeast, which would fulfill this demand and thereby save the country enormous expenses. The principal purpose of the present study was to optimize the cultivation conditions of indigenous wild yeasts isolated from local fermented foods and beverages and compared to the commercial baker's yeast based on their leavening ability in wheat dough.

\section{Materials and methods \\ Wild yeast isolates and their growth medium}

Yeasts isolated from fermented foods (teff dough, wheat dough), fermented beverages (Tej, shamita) and molasses including the commercial yeast (control) were grown on yeast extract peptone dextrose agar (YEPDA). The isolates were transferred to respective slant medium and preserved at $4^{\circ} \mathrm{C}$ for further study. The yeast strains used in this study were obtained from my previous research result and were identified using molecular method and the nucleotide sequence was performed at Genwiz, USA. Yeast species name used in this experiment, designation and their source are listed in table 1.

Table 1: Yeast species name, designation and their source

\begin{tabular}{lll}
\hline Species name & Designation & Source \\
\hline Candida humilis $(\mathrm{KY} 102138.1, \mathrm{CBS})$ & AAUTf & Teff dough \\
Kazachstania bulderi (KY103628.1, CBS) & AAUTf & Teff dough \\
Saccharomyces cerevisiae (KY105143.1, CBS) & AAUSh & Shamita \\
Saccharomyces cerevisiae (KY630581.1, CBS) & AAUTj & Tej \\
Pichia kudriavzevii $(\mathrm{KY} 104596.1, \mathrm{CBS})$ & AAUWt & Wheat dough \\
Pichia fermentans $(\mathrm{KY} 104550.1, \mathrm{CBS})$ & AAUMl & Molasses \\
\hline
\end{tabular}

\section{Optimization of cultivation conditions for yeast growth}

Effect of $\mathrm{pH}$ on yeasts growth

Isolated yeasts and control (commercial yeast) were separately cultured in yeast extract peptone dextrose (YEPD) broth containing yeast extract $1.0 \%$, peptone $2.0 \%$, and dextrose $2.0 \%$. The $\mathrm{pH}$ values were adjusted to $3.5,4,4.5,5$ and 5.5 and incubated at $30^{\circ} \mathrm{C}$ for 48 hours under shaking at $120 \mathrm{rpm}$ (Qureshi et al., 2007). Two $250 \mathrm{ml}$ flasks containing $50 \mathrm{ml}$ broth for the listed $\mathrm{pH}$ values were each inoculated with $1 \mathrm{ml}$ of a 48 hour-old yeast culture (approximately $1.2 \times 10^{8} \mathrm{CFU}$ ) separately. Optical densities at $600 \mathrm{~nm}$ were determined using a spectrophotometer (UV-VIS spectrophotometer, USA) as a measure of growth. The culture medium was used as blank.

\section{Effect of temperature on yeast growth}

The ability of the isolates including the control to grow at different temperature values was examined by inoculating duplicate flasks with $50 \mathrm{ml}$ YEPD broth medium. The experiment was arranged at four different temperatures values $\left(25,30,35\right.$, and $\left.40^{\circ} \mathrm{C}\right)$ and at optimum $\mathrm{pH} 5.5$ (a result of this study), inoculated with the same number of actively grown yeast cells (48 hours old), $1 \mathrm{ml}$ (approximately 1.2 $\left.\mathrm{x} 10^{8} \mathrm{CFU}\right)$. After 48 hours of incubation optical density were determined the same method as indicated above.

\section{Determination of optimum length of time for yeasts growth}

The optimum time of incubation for a maximum cell biomass production of each yeast isolate and control (commercial yeast) was determined by incubating cultures at optimum temperature $\left(30^{\circ} \mathrm{C}\right.$; result of this 
study) for $24,48,72,96$ and 120 hours. The same number of active yeast cells grown in YEPD for 48 hours, $1 \mathrm{ml}$ (approximately $1.2 \times 10^{8} \mathrm{CFU}$ ) was inoculated in duplicates in $50 \mathrm{ml}$ YEPD broth in 250 $\mathrm{ml}$ flasks. The best incubation time for growth and maximum biomass production was detected by measuring optical density as indicated above.

\section{The interaction effect of temperature, $\mathrm{pH}$ and incubation time on yeast growth}

The 48 hours old yeast $\left(30^{\circ} \mathrm{C}, 120 \mathrm{rpm}\right)$ cultured in YEPD broth were inoculated with the same number of actively grown yeast cells $1 \mathrm{ml}$ (approximately 1.2 $\left.\mathrm{x} 10^{8} \mathrm{CFU}\right)$ at five $\mathrm{pH}$ levels $(3.5,4,4.5,5$ and 5.5) and incubated at $25,30,35$ and $40^{\circ} \mathrm{C}$ being shaken at $120 \mathrm{rpm}$ for five days. Samples were taken and analyzed at interval of 24, 48, 72, 96 and 120 hours. Optimum temperature, $\mathrm{pH}$ and incubation time for yeast growth and maximum biomass production were determined by using spectrophotometer at $600 \mathrm{~nm}$ (UV-VIS spectrophotometer, USA).

\section{Test of hydrogen sulfide production}

To examine production $\mathrm{H}_{2} \mathrm{~S}$ (associated with an offflavor and unpleasant taste), test strains and the control (commercial yeast) were streak cultured on Bismuth Sulfate Agar (BSA) plates and incubated at $30^{\circ} \mathrm{C}$ for 2 days. Colonies that exhibited significant black color along the line of inoculation on BSA plates indicated hydrogen sulfide production (Jiranek et al., 1995). Positive strains were discarded as their palatability for humans is compromised.

\section{Preparation of wheat bread with selected yeast isolates}

\section{Analysis of bread leavening potential of selected} yeasts

Bread dough was prepared with candidate isolates to observe the baking potency according to Zaky and Nasr (2011). Selected yeast species and the control for dough making were grown in YEPD broth for 48 hours at optimum temperature of $30^{\circ} \mathrm{C}$ being shaken at $120 \mathrm{rpm}$. Samples $(10 \mathrm{ml}$ each $)$ were centrifuged for $10 \mathrm{~min}$ at $5,000 \mathrm{rpm}$, washed twice with deionized water, and the supernatant was discarded. The sedimented yeast biomass with moisture was transferred to pre-weighed filter paper, dried overnight at $60^{\circ} \mathrm{C}$, and stored in a desiccator until a constant weight was obtained (Milkessa and Abate, 2014). The yeast culture was harvested and weighed using an analytical balance (FA2104, China).

Prepared dough for this assay contained wheat flour $(50 \mathrm{~g})$, harvested yeast culture $(0.5 \mathrm{~g})$, table sugar $(0.2 \mathrm{~g})$. These ingredients were properly mixed with distilled water $(40 \mathrm{ml})$ and added into $250 \mathrm{ml}$ measuring cylinders. Commercial yeast (Saf- instant, from Turkey) was used separately as a positive control to ferment the dough. Another set of dough formulation that did not contain any yeast sample was prepared as the negative control. The dough samples were left to ferment at ambient $\left(24^{\circ} \mathrm{C}\right)$ and $30^{\circ} \mathrm{C}$ temperatures for 3 hours. The dough volume was determined by measuring the mean of volume increment at every $30 \mathrm{~min}$ interval for 3 hours. All dough samples were covered using aluminum foil.

\section{Formulation of mixed culture and testing bread leavening potential}

The effect of combined (mixed) yeast culture on leavening activity was evaluated. Dough was prepared with commercial yeast and without yeast as positive and negative control. The ingredients used for the dough preparation were wheat flour (50 g), harvested yeast culture $(0.5 \mathrm{~g})$, table sugar $(0.2 \mathrm{~g})$ and distilled water $(40 \mathrm{ml})$. The ingredients were mixed to homogeneity and incubated at the optimum temperature of $30^{\circ} \mathrm{C}$ (based on previous result of this study). Single and mixed isolates of yeast cultures used for this test are listed in (Table 2). Two replicates were performed for each type of dough fermentation. The rising power of the combined (mixed) and single (mono) yeast was determined by recording the dough volume increment starting from zero to two hours at $30 \mathrm{~min}$ interval. Aluminum foil was used to cover the dough containing measuring cylinders. 
Table 2: Formulation for bread dough preparation.

\begin{tabular}{|c|c|c|c|c|c|}
\hline Mixed culture & $\begin{array}{l}\text { Harvested yeast culture } \\
\text { in gram }\end{array}$ & Wheat flour in gram & $\begin{array}{l}\text { Table } \\
\text { gram }\end{array}$ & sugar in & $\mathrm{dH}_{2} \mathrm{O}$ in $\mathrm{ml}$ \\
\hline $\mathrm{X} 1$ & 0.5 & 50 & 0.2 & & 40 \\
\hline $\mathrm{X} 2$ & 0.5 & 50 & 0.2 & & 40 \\
\hline $\mathrm{X} 3$ & 0.5 & 50 & 0.2 & & 40 \\
\hline $\mathrm{X} 4$ & 0.5 & 50 & 0.2 & & 40 \\
\hline X5 & 0.5 & 50 & 0.2 & & 40 \\
\hline X6 & 0 & 50 & 0.2 & & 40 \\
\hline $\mathrm{X} 1+\mathrm{X} 2$ & 0.5 & 50 & 0.2 & & 40 \\
\hline $\mathrm{X} 1+\mathrm{X} 3$ & 0.5 & 50 & 0.2 & & 40 \\
\hline $\mathrm{X} 1+\mathrm{X} 4$ & 0.5 & 50 & 0.2 & & 40 \\
\hline $\mathrm{X} 2+\mathrm{X} 3$ & 0.5 & 50 & 0.2 & & 40 \\
\hline $\mathrm{X} 2+\mathrm{X} 4$ & 0.5 & 50 & 0.2 & & 40 \\
\hline $\mathrm{X} 3+\mathrm{X} 4$ & 0.5 & 50 & 0.2 & & 40 \\
\hline $\mathrm{X} 1+\mathrm{X} 2+\mathrm{X} 3$ & 0.5 & 50 & 0.2 & & 40 \\
\hline $\mathrm{X} 2+\mathrm{X} 3+\mathrm{X} 4$ & 0.5 & 50 & 0.2 & & 40 \\
\hline $\mathrm{X} 1+\mathrm{X} 3+\mathrm{X} 4$ & 0.5 & 50 & 0.2 & & 40 \\
\hline $\mathrm{X} 1+\mathrm{X} 2+\mathrm{X} 3+\mathrm{X} 4$ & 0.5 & 50 & 0.2 & & 40 \\
\hline
\end{tabular}

Note: nomination for isolates X1 (AAUTf1), X2 (AAUTf5), X3 (AAUTj15), X4 (AAUSh17), X5 (+ve control/commercial yeast), X6 (-Ve control)

\section{Statistical analysis of the experiments}

The analysis of variance (ANOVA) of the different sets of experiments or combinations was performed using R software version 3.3.1 (Team RC, 2016). The mean comparison was made using least significant difference (LSD) test at 5\% significant level.

\section{Results}

\section{Optimization of cultivation conditions for yeast} growth

The effect of $\mathrm{pH}$ on yeast biomass

Growth of the isolates varied at different $\mathrm{pH}$ values (Table 3). Although all isolates grew at each of the
$\mathrm{pH}$ levels tested, the minimum and maximum growth yield was observed at $\mathrm{pH} 3.5$ and 5.5 values, respectively. The maximum biomass yields of OD reading at $600 \mathrm{~nm}$ reading at $\mathrm{pH} 5.5$ for isolate AAUM120, AAUSh17, AAUWt21 and AAUTj15 were $2.57,2.45,2.25$ and 2.23 respectively. Isolate AAUM120 was found to gain the highest biomass yield at the same $\mathrm{pH}$ value. However, the maximum biomass yield (1.844) for the control was achieved at $\mathrm{pH}$ 5. There were significant $(\mathrm{p}<0.05)$ differences among the biomass yield of the isolates at each $\mathrm{pH}$ values (Table 3 ).

Table 3: Mean biomass of Yeasts under different $\mathrm{pH}$ ranges

\begin{tabular}{llllll}
\hline Isolate & $\mathbf{p H 3 . 5}$ & $\mathbf{p H 4}$ & $\mathbf{p H 4 . 5}$ & $\mathbf{p H 5}$ & $\mathbf{p H 5 . 5}$ \\
\hline AAUTf1 & $0.64^{\text {op }}$ & $1.56^{\text {defgh }}$ & $1.50^{\text {defghi }}$ & $1.82^{\text {bcdef }}$ & $1.91^{\text {bcde }}$ \\
AAUTf5 & $0.57^{\text {p }}$ & $1.43^{\text {fghij }}$ & $1.51^{\text {defghi }}$ & $1.63^{\text {defgh }}$ & $1.85^{\text {bcdef }}$ \\
AAUTj15 & $0.76^{\text {mnop }}$ & $1.28^{\text {ghijk }}$ & $1.2^{\text {hijklm }}$ & $1.56^{\text {detgh }}$ & $2.23^{\text {abc }}$ \\
AAUSh17 & $0.74^{\text {nop }}$ & $1.05^{\text {jklmno }}$ & $1.2^{\text {hijklm }}$ & $1.81^{\text {bcdef }}$ & $2.45^{\text {a }}$ \\
AAUM120 & $0.83^{\text {lmnop }}$ & $1.09^{\text {ijklmn }}$ & $1.25^{\text {ghijkl }}$ & $1.47^{\text {etghij }}$ & $2.57^{\text {a }}$ \\
AAUWt21 & $0.73^{\text {nop }}$ & $0.97^{\text {klmnop }}$ & $1.68^{\text {defg }}$ & $1.94^{\text {bcd }}$ & $2.25^{\text {ab }}$ \\
Control & $1.67^{\text {defg }}$ & $1.68^{\text {defg }}$ & $1.67^{\text {defg }}$ & $1.84^{\text {bcdef }}$ & $1.77^{\text {cdef }}$ \\
\hline
\end{tabular}

Note: CY stands for commercial yeast

Means with the same letter are not significantly different at $\mathrm{p}<0.05$.

The effect of temperature on yeast biomass

The yeast isolates grew at all temperature values (Table 4). The maximum biomass yield for all the six yeast isolates and the control was at $30^{\circ} \mathrm{C}$ and the minimum biomass yield for all the isolates (including the control) was above $35^{\circ} \mathrm{C}$. At $30^{\circ} \mathrm{C}$, the AAUMl20 isolate exhibited the maximal growth but biomass yield of all the isolates was significantly higher at $30^{\circ} \mathrm{C}$ than at all other temperature values $\left(25^{\circ} \mathrm{C}, 35^{\circ} \mathrm{C}\right.$ and $40^{\circ} \mathrm{C}$ ) (Table 4). 
Table 4: Mean biomass of potent yeasts under different temperature ranges (values given are O.D.600).

\begin{tabular}{lllll}
\hline Isolate & $\mathbf{2 5}^{\mathbf{0}} \mathbf{C}$ & $\mathbf{3 0}^{\mathbf{0}} \mathbf{C}$ & $\mathbf{3 5}^{\mathbf{0}} \mathbf{C}$ & $\mathbf{4 0}^{\mathbf{0}} \mathbf{C}$ \\
\hline AAUTf1 & $0.6^{\mathrm{hijk}}$ & $1.9^{\mathrm{d}}$ & $0.56^{\mathrm{hjk}}$ & $0.47^{\mathrm{jk}}$ \\
AAUTf5 & $0.61^{\mathrm{hij}}$ & $1.87^{\mathrm{de}}$ & $0.58^{\mathrm{hijk}}$ & $0.40^{\mathrm{k}}$ \\
AAUTj15 & $0.56^{\mathrm{hijk}}$ & $2.21^{\mathrm{c}}$ & $0.59^{\mathrm{hijk}}$ & $0.46^{\mathrm{jk}}$ \\
AAUSh17 & $0.64^{\mathrm{hij}}$ & $2.39^{\mathrm{ab}}$ & $0.72^{\mathrm{h}}$ & $0.52^{\mathrm{hijk}}$ \\
AAUM120 & $0.67^{\mathrm{hi}}$ & $2.6^{\mathrm{a}}$ & $0.69^{\mathrm{hi}}$ & $0.53^{\mathrm{hijk}}$ \\
AAUWt21 & $0.51^{\mathrm{ijk}}$ & $2.27^{\mathrm{bc}}$ & $0.57^{\mathrm{hijk}}$ & $0.52^{\mathrm{ijk}}$ \\
control & $1.42^{\mathrm{f}}$ & $1.79^{\mathrm{de}}$ & $1.63^{\mathrm{e}}$ & $1.11^{\mathrm{g}}$ \\
\hline
\end{tabular}

Note: CY stands for commercial yeast

Means with the same letter are not significantly different at $\mathrm{p}<0.05$.

Effect of incubation period on yeast biomass yield The effect of incubation time on the growth rates of the six isolates and the control at optimum temperature $\left(30^{\circ} \mathrm{C}\right)$ and $\mathrm{pH}$ of 5.5 is shown in Table 5. Maximum biomass yield was obtained for all the yeast isolates of this study at 48 hours but the minimum biomass yield was recorded decreasing thereafter to the minimum level at 120 hours. Isolate AAUMl20 achieved the highest biomass yield (2.57,
$\left.\mathrm{OD}_{600 \mathrm{~nm}}\right)$ at 48 hours of incubation time and optimum temperature $30^{\circ} \mathrm{C}$ followed by isolate AAUSh 17 $\left(2.41, \mathrm{OD}_{600 \mathrm{~nm}}\right)$ under the same incubation time and temperature. Table 5 documents the biomass yield for all isolates and we conclude from these results that, except for the control with an optimal incubation time of 72 hours, all other isolates peaked growth characteristics at 48 hours.

Table 5: Mean growth of Yeasts under different incubation time ranges $\left(\mathrm{OD}_{600 \mathrm{~nm}}\right)$

\begin{tabular}{llllll}
\hline Isolate & $\mathbf{2 4}$ hours & $\mathbf{4 8}$ hours & $\mathbf{7 2}$ hours & $\mathbf{9 6 ~ h o u r s}$ & $\mathbf{1 2 0}$ hours \\
\hline AAUTf1 & $1.6^{\text {gh }}$ & 1.96 & $1.05^{\mathrm{jk}}$ & $0.59^{\mathrm{o}}$ & $0.36^{\mathrm{q}}$ \\
AAUTf5 & $1.49^{\mathrm{h}}$ & $1.81^{\mathrm{ef}}$ & $0.79^{\mathrm{n}}$ & $0.94^{\mathrm{klm}}$ & $0.52^{\mathrm{op}}$ \\
AAUTj15 & $1.68^{\mathrm{efg}}$ & $2.12^{\mathrm{cd}}$ & $1.33^{\mathrm{i}}$ & $0.84^{\mathrm{mn}}$ & $0.61^{\mathrm{o}}$ \\
AAUSh17 & $1.79^{\mathrm{ef}}$ & $2.43^{\mathrm{b}}$ & $0.91^{\mathrm{lmn}}$ & $0.81^{\mathrm{mn}}$ & $0.43^{\mathrm{pq}}$ \\
AAUM120 & $1.7^{\mathrm{efg}}$ & $2.6^{\mathrm{a}}$ & $0.99^{\mathrm{kl}}$ & $0.83^{\mathrm{mn}}$ & $0.43^{\mathrm{pq}}$ \\
AAUWt21 & $1.66^{\mathrm{fg}}$ & $2.21^{\mathrm{c}}$ & $1.15^{\mathrm{j}}$ & $0.98^{\mathrm{kl}}$ & $0.53^{\mathrm{op}}$ \\
CY(Control) & $1.31^{\mathrm{i}}$ & $1.74^{\mathrm{efg}}$ & $1.99^{\mathrm{cd}}$ & $1.81^{\mathrm{e}}$ & $1.8^{\mathrm{e}}$ \\
\hline
\end{tabular}

Note: CY stands for commercial yeast

Means with the same letter are not significantly different at $\mathrm{p}<0.05$.

\section{Combined effect of temperature, $\mathrm{pH}$ and incubation time on yeast biomass yield}

The maximum cell density $1.89,1.82,2.17,2.41$, 2.56 and 2.23 of OD at $600 \mathrm{~nm}$ for isolates AAUTf1, AAUTf5, AAUTj15, AAUSh17, AAUM120 and AAUWt 21 respectively, were obtained at $30^{\circ} \mathrm{C}, \mathrm{pH}$ 5.5 and 48 hours of incubation (data not shown). On the other hand, the maximum biomass yield for control yeast $\left(2.0, \mathrm{OD}_{600 \mathrm{~nm}}\right)$ was achieved when the temperature, $\mathrm{pH}$ and incubation time was at $30^{\circ} \mathrm{C}, 5$ and 72 hours, respectively. We observed a significant difference $(p<0.05)$ among the treatments on the combined effect of temperature, $\mathrm{pH}$ and incubation time with regard to biomass yield. The minimum biomass yield was measured for the isolates AAUTf1 (0.21), AAUTf5 (0.25), AAUTj15 (0.27), AAUSh17 (0.28), AAUM120 (0.35), AAUWt21 (0.28) and control $\left(0.49, \mathrm{OD}_{600 \mathrm{~nm}}\right)$ at $40^{\circ} \mathrm{C}, 3.5 \mathrm{pH}$ and 120 hours of incubation time.

\section{Hydrogen sulfide production by yeast isolates}

On the basis of their $\mathrm{H}_{2} \mathrm{~S}$ production (Fig. 1), the isolates were grouped into three categories (nonproducers, low level and high level of $\mathrm{H}_{2} \mathrm{~S}$ producers). Accordingly, isolate AAUTf1 did not produce hydrogen sulfide (Fig. 1, A), while AAUTf5, AAUTj15 and AAUSh17 produced low levels of hydrogen sulfide. The commercial yeast also produces low levels $\mathrm{H}_{2} \mathrm{~S}$ as well (Fig 1, B). Isolates AAUM120 and AAUWt21 produced high level of hydrogen sulfide (Fig. 1, C). Therefore, AAUTf1, AAUTf5, AAUTj15 and AAUSh17 were subjected for further test. 

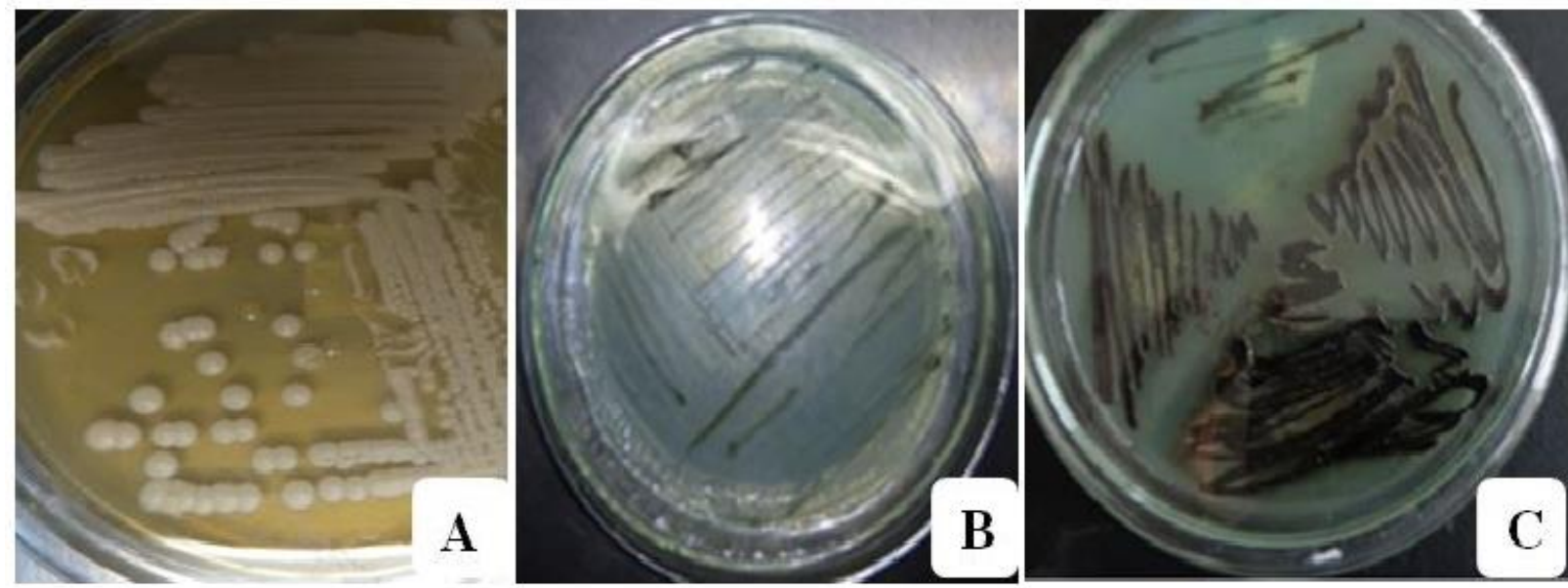

Fig. 1: Hydrogen sulfide $\left(\mathrm{H}_{2} \mathrm{~S}\right)$ gas production by isolates as detected by black readout on Bismuth Sulphate Agar plates. A (AAUTf1) - non producer; B (AAUTf5, AAUTj15, AAUSh17 and Commercial yeast) - low level and C (AAUM120 and AAUWt21) - high level

\section{Leavening capacity of isolated yeast strains}

The leavening capacity of the non-hydrogen sulphide producer, $C$. humilis strain (AAUTf1), and the low $\mathrm{H}_{2} \mathrm{~S}$ producers $K$. bulderi strain (AAUTf5), $S$. cerevisiae strain (AAUTj15), and $S$. cerevisiae strain (AAUSh17) were compared to the commercial $S$. cerevisiae. The results showed that the period of bread dough fermentation at $30^{\circ} \mathrm{C}$ was short (2 hours) compared to ambient temperature (Table 6). The maximum mean of leavening activity was seen by isolate AAUTf1 $\left(131 \mathrm{~cm}^{3}\right)$ at $120 \mathrm{~min}$, which was followed by AAUTf5 $\left(128 \mathrm{~cm}^{3}\right)$ at $120 \mathrm{~min}$ at $30^{\circ} \mathrm{C}$.
Similarly, isolates AAUSh17 $\left(127 \mathrm{~cm}^{3}\right)$ and AAUTj15 (125 $\left.\mathrm{cm}^{3}\right)$ achieved high leavening activity at $60 \mathrm{~min}$ at the same temperature, which was not significantly different $(p>0.05)$ with the above isolates (AAUTf1 and AAUTf5). The commercial yeasts had $117 \mathrm{~cm}^{3}$ mean rising capacity at $90 \mathrm{~min}$ which is lower, and takes longer $(p<0.05)$ than that of the indigenous isolates. Dough left to ferment without yeast (negative control) did not show volume increment within 3 hours of dough fermentation (Table 6).

Table 6: Leavening activity of yeast strains at $24^{\circ} \mathrm{C}$ and $30^{\circ} \mathrm{C}$ temperature

\begin{tabular}{|c|c|c|c|c|c|c|c|c|}
\hline \multirow[t]{2}{*}{ Isolates } & \multirow[t]{2}{*}{ Temp } & \multicolumn{7}{|c|}{ Mean of rising dough volume $\left(\mathrm{cm}^{3}\right) /$ Time (min) } \\
\hline & & $0 \mathrm{~min}$ & $30 \mathrm{~min}$ & $60 \mathrm{~min}$ & $90 \mathrm{~min}$ & $120 \mathrm{~min}$ & $150 \mathrm{~min}$ & $180 \mathrm{~min}$ \\
\hline \multirow[t]{2}{*}{ AAUTf1 } & $24^{\circ} \mathrm{C}$ & $0^{\mathrm{i}}$ & $12^{\text {hi }}$ & $26^{\mathrm{g}-\mathrm{i}}$ & $50^{\mathrm{d}-\mathrm{i}}$ & $63^{\mathrm{a}-\mathrm{g}}$ & $70^{\mathrm{a}-\mathrm{g}}$ & $109^{\mathrm{ab}}$ \\
\hline & $30^{\circ} \mathrm{C}$ & $0^{1}$ & $32^{\mathrm{kl}}$ & $46^{\mathrm{i}-\mathrm{k}}$ & $73^{e-j}$ & $131^{\mathrm{a}}$ & $110^{\mathrm{a}-\mathrm{e}}$ & $84^{\mathrm{c}-\mathrm{h}}$ \\
\hline \multirow[t]{2}{*}{ AAUTf5 } & $24^{\circ} \mathrm{C}$ & $0^{\mathrm{i}}$ & $35^{\mathrm{f}-\mathrm{i}}$ & $51^{\mathrm{d}-\mathrm{h}}$ & $75^{\mathrm{a}-\mathrm{g}}$ & $97^{\mathrm{a}-\mathrm{d}}$ & $81^{\mathrm{a}-\mathrm{f}}$ & $70^{\mathrm{a}-\mathrm{g}}$ \\
\hline & $30^{\circ} \mathrm{C}$ & $0^{1}$ & $40^{\mathrm{jk}}$ & $80 \mathrm{~d}^{-\mathrm{i}}$ & $111^{\mathrm{b}-\mathrm{d}}$ & $128^{\mathrm{a}}$ & $124^{\mathrm{ab}}$ & $81^{\mathrm{d}-\mathrm{i}}$ \\
\hline \multirow[t]{2}{*}{ AAUTj15 } & $24^{\circ} \mathrm{C}$ & $0^{\mathrm{i}}$ & $60^{\mathrm{b}-\mathrm{h}}$ & $113^{\mathrm{a}}$ & $116^{\mathrm{a}}$ & $87^{\mathrm{a}-\mathrm{e}}$ & $73^{\mathrm{a}-\mathrm{g}}$ & $67^{\mathrm{a}-\mathrm{g}}$ \\
\hline & $30^{\circ} \mathrm{C}$ & $0^{1}$ & $49^{\mathrm{g}-\mathrm{k}}$ & $125^{\mathrm{ab}}$ & $110^{\mathrm{b}-\mathrm{d}}$ & $81^{\mathrm{d}-\mathrm{i}}$ & $84^{\mathrm{c}-\mathrm{h}}$ & $77^{\mathrm{d}-\mathrm{j}}$ \\
\hline \multirow[t]{2}{*}{ AAUSh17 } & $24^{\circ} \mathrm{C}$ & $0^{\mathrm{i}}$ & $51^{\mathrm{d}-\mathrm{h}}$ & $55^{\mathrm{c}-\mathrm{h}}$ & $59^{\mathrm{b}-\mathrm{h}}$ & $98^{\mathrm{a}-\mathrm{d}}$ & $86^{\mathrm{a}-\mathrm{f}}$ & $82^{\mathrm{a}-\mathrm{f}}$ \\
\hline & $30^{\circ} \mathrm{C}$ & $0^{1}$ & $48^{\mathrm{h}-\mathrm{k}}$ & $127^{\mathrm{a}}$ & $103^{b-e}$ & $78^{\mathrm{d}-\mathrm{i}}$ & $86^{\mathrm{b}-\mathrm{g}}$ & $63^{\mathrm{f}-\mathrm{k}}$ \\
\hline \multirow[t]{2}{*}{ CY } & $24{ }^{\circ} \mathrm{C}$ & $0^{\mathrm{i}}$ & $39^{e-i}$ & $90^{\mathrm{a}-\mathrm{d}}$ & $100^{\mathrm{a}-\mathrm{d}}$ & $103^{a-c}$ & $80^{\mathrm{a}-\mathrm{f}}$ & $73^{\mathrm{a}-\mathrm{g}}$ \\
\hline & $30^{\circ} \mathrm{C}$ & $0^{1}$ & $47^{\mathrm{h}-\mathrm{k}}$ & $101^{\mathrm{b}-\mathrm{e}}$ & $117^{\mathrm{b}-\mathrm{c}}$ & $103^{\mathrm{b}-\mathrm{e}}$ & $95^{\mathrm{b}-\mathrm{f}}$ & $78^{\mathrm{d}-\mathrm{i}}$ \\
\hline \multirow[t]{2}{*}{$\mathrm{NC}$} & $24^{\circ} \mathrm{C}$ & $0^{\mathrm{i}}$ & $0^{\mathrm{i}}$ & $0^{\mathrm{i}}$ & $0^{\mathrm{i}}$ & $0^{\mathrm{i}}$ & $0^{\mathrm{i}}$ & $0^{\mathrm{i}}$ \\
\hline & $30^{\circ} \mathrm{C}$ & $0^{1}$ & $0^{1}$ & $0^{1}$ & $0^{1}$ & $0^{1}$ & $0^{1}$ & $0^{1}$ \\
\hline
\end{tabular}

Note: CY- commercial yeast; $\mathrm{NC}$ - negative control.

Means with the same letter are not significantly different at $\mathrm{p}<0.05$.

\section{Effect of mixed yeast cultures on leavening activity}

The combined ability of the four selected yeast isolates AAUTf1 (C. humilis), AAUTf5 (K. bulderi), AAUTj15 (S.cerevisiae) and AAUSh17 (S.cerevisiae) on bread dough leavening was tested for additive properties of the yeast. Co-inoculated isolates were compared for their leavening effect to each of the separate isolates and to that of the control, commercial yeast. Results of the three co-inoculated isolates (AAUTf1+ AAUTf5 + AAUTj15) were found highest $\left(143 \mathrm{~cm}^{3}\right)$ at $90 \mathrm{~min}$; while the raising volume 
of dough of as result of co-inoculation of different combination of two (AAUTf5 + AAUTj15) and three (AAUTf1 + AAUTj15 + AAUSh17) yeast isolates was as high as 141 and $140 \mathrm{~cm}^{3}$ respectively at $60 \mathrm{~min}$ (Table 7). The aroma of the dough prepared using combined isolates was judged better than of the dough prepared by single isolates and the commercial bakery yeast, though admittedly, this is a subjective measurement (data not included).

Table 7: Leavening activity of mixed and pure isolates

\begin{tabular}{|c|c|c|c|c|c|}
\hline \multirow[t]{2}{*}{ Isolate/S } & \multicolumn{5}{|c|}{ Mean of rising dough volume $\left(\mathrm{cm}^{3}\right)$ at time (min) } \\
\hline & 0 min & $30 \mathrm{~min}$ & $60 \mathrm{~min}$ & $90 \mathrm{~min}$ & $120 \mathrm{~min}$ \\
\hline $\mathrm{X} 1$ & $0^{\mathrm{B}}$ & $32^{\mathrm{zA}}$ & $46^{\mathrm{w}-\mathrm{A}}$ & $73^{\mathrm{n}-\mathrm{w}}$ & $131^{\mathrm{a}-\mathrm{c}}$ \\
\hline $\mathrm{X} 2$ & $0^{\mathrm{B}}$ & $40^{\mathrm{y}-\mathrm{A}}$ & $80^{1-t}$ & $111^{\mathrm{c}-\mathrm{j}}$ & $128^{\mathrm{a}-\mathrm{d}}$ \\
\hline X3 & $0^{\mathrm{B}}$ & $49^{\mathrm{v}-\mathrm{z}}$ & $125^{\mathrm{a}-\mathrm{e}}$ & $87^{\mathrm{h}-\mathrm{t}}$ & $81^{\mathrm{k}-\mathrm{t}}$ \\
\hline $\mathrm{X} 4$ & $0^{\mathrm{B}}$ & $48^{\mathrm{w}-\mathrm{z}}$ & $127^{\mathrm{a}-\mathrm{d}}$ & $93^{\mathrm{g}-\mathrm{r}}$ & $78^{1-u}$ \\
\hline $\mathrm{X} 5$ & $0^{\mathrm{B}}$ & $47^{\mathrm{w}-\mathrm{A}}$ & $101^{\mathrm{d}-\mathrm{n}}$ & $117^{\mathrm{b}-\mathrm{h}}$ & $103^{\mathrm{c}-\mathrm{m}}$ \\
\hline X6 & $0^{\mathrm{B}}$ & $0^{\mathrm{B}}$ & $0^{\mathrm{B}}$ & $0^{\mathrm{B}}$ & $0^{\mathrm{B}}$ \\
\hline $\mathrm{X} 1 \mathrm{X} 2$ & $0^{\mathrm{B}}$ & $49^{v-z}$ & $102^{\mathrm{d}-\mathrm{m}}$ & $68^{q-y}$ & $68^{q-y}$ \\
\hline $\mathrm{X} 1 \mathrm{X} 3$ & $0^{\mathrm{B}}$ & $44^{\mathrm{x}-\mathrm{A}}$ & $98^{\mathrm{e}-\mathrm{o}}$ & $94^{\mathrm{g}-\mathrm{r}}$ & $83^{\mathrm{j}-\mathrm{t}}$ \\
\hline $\mathrm{X} 1 \mathrm{X} 4$ & $0^{\mathrm{B}}$ & $19^{\mathrm{AB}}$ & $96^{\mathrm{f}-\mathrm{q}}$ & $85^{\mathrm{j}-\mathrm{t}}$ & $66^{r-y}$ \\
\hline $\mathrm{X} 2 \mathrm{X} 3$ & $0^{\mathrm{B}}$ & $100^{\mathrm{d}-\mathrm{n}}$ & $141^{\mathrm{ab}}$ & $121^{\mathrm{a}-\mathrm{h}}$ & $86^{\mathrm{i}-\mathrm{t}}$ \\
\hline $\mathrm{X} 2 \mathrm{X} 4$ & $0^{\mathrm{B}}$ & $33^{\mathrm{zA}}$ & $124^{\mathrm{a}-\mathrm{f}}$ & $109^{c-k}$ & $63^{s-y}$ \\
\hline X3X4 & $0^{\mathrm{B}}$ & $64^{\mathrm{s}-\mathrm{y}}$ & $114^{\mathrm{b}-\mathrm{i}}$ & $77^{\mathrm{m}-\mathrm{v}}$ & $69^{\mathrm{p}-\mathrm{x}}$ \\
\hline $\mathrm{X} 1 \mathrm{X} 2 \mathrm{X} 3$ & $0^{\mathrm{B}}$ & $19^{\mathrm{AB}}$ & $97^{\mathrm{e}-\mathrm{p}}$ & $143^{\mathrm{a}}$ & $98^{\mathrm{e}-\mathrm{o}}$ \\
\hline $\mathrm{X} 2 \mathrm{X} 3 \mathrm{X} 4$ & $0^{\mathrm{B}}$ & $50^{\mathrm{u}-\mathrm{z}}$ & $128^{\mathrm{a}-\mathrm{d}}$ & $93^{\mathrm{g}-\mathrm{r}}$ & $71^{0-\mathrm{x}}$ \\
\hline $\mathrm{X} 1 \mathrm{X} 3 \mathrm{X} 4$ & $0^{\mathrm{B}}$ & $59^{t-z}$ & $140^{\mathrm{ab}}$ & $106^{\mathrm{c}-\mathrm{l}}$ & $89^{\mathrm{h}-\mathrm{s}}$ \\
\hline $\mathrm{X} 1 \mathrm{X} 2 \mathrm{X} 3 \mathrm{X} 4$ & $0^{\mathrm{B}}$ & $51^{\mathrm{u}-\mathrm{z}}$ & $125^{\mathrm{a}-\mathrm{e}}$ & $109^{\mathrm{c}-\mathrm{k}}$ & $89^{\mathrm{h}-\mathrm{s}}$ \\
\hline
\end{tabular}

Note: nomination for isolates X1-AAUTf1; X2-AAUTf5; X3-AAUTj15; X4-AAUSh17; X5-CY (Positive control); X6- Negative control.

Means with the same letter are not significantly different at $\mathrm{p}<0.05$.

\section{Discussion}

The metabolic and production efficiency of cells depends on many factors such as temperature, $\mathrm{pH}$, incubation period, inoculums size, genetic background (Supanwong et al., 1983). All the isolates, Candida humilis (AAUTf1), Kazachitania bulderi (AAUTf5), Saccharomyces cerevisiae (AAUTj15 and AAUSh17), Pichia fermentans (AAUM120) and Pichia kudrvizivi (AAUWt21) showed higher biomass at $\mathrm{pH}$ of 5.5, temperature of $30^{\circ} \mathrm{C}$ and incubation time of 48 hours, while the commercial yeast (control) had less biomass. This result shows that the isolated yeasts (this study) had shorter growth times than that of the commercial yeast strain. Similar to this result, Dechassa (2010) has found that yeasts grew maximally at $\mathrm{pH} 5$ to 5.5, $30^{\circ} \mathrm{C}$ temperature and 72 hours of incubation period.

All the yeast species and strains in this study could tolerate a temperature up to $40^{\circ} \mathrm{C}$ including the control (Table 4). The ability of yeast to tolerate high temperature suggests that the isolates can withstand excess heat associated with fermentation process and therefore can be used to accomplish fermentation at a wide range of temperature condition. In agreement with this study, Choi and Peterson (2010); Nitayavardhana et al., (2010) have also reported that yeasts can grow at elevated temperatures of $40^{\circ} \mathrm{C}$, but the optimal temperature is approximately $30^{\circ} \mathrm{C}$.

In the current study, a maximum biomass was obtained at 48 hours of incubation period but the biomass decreased with increasing incubation time. This is supported by the scientific fact that the stationary phase of yeast growth is a period of no growth, when metabolism slows and cell division is stopped due to nutrient deprivation, toxic metabolites and high temperatures which led cells to die and autolyse. In contrary to the present study, MamunOr-Rashid et al., (2013) have stated that the highest biomass was recorded after 144 hours of incubation period. The difference in these results may be due to the genetic constituent of their cells and cultivation conditions.

The current study has indicated that isolate AAUTf1 did not produce hydrogen sulfide, while AAUTf5, AAUTj15 and AAUSh17 including the commercial yeast produced lower content of this undesirable gas and yet other isolates produced intense dark color on Bismith Sulfate Agar (BSA) medium (Jiranek et al., 1995). Fellers et al., (1924) also reported that the highly darkened color in Lead Acetate Agar (LAA) indicates a greater amount of hydrogen sulfide production. Therefore, some of the wild yeast isolates 
in the present study could be a potential candidate for wheat dough leavening for bread making since they showed low production of $\mathrm{H}_{2} \mathrm{~S}$ and also had better fermentation ability than the commercial yeast. Furthermore, Noroul et al., (2013) have demonstrated that yeast strains isolated from fruits and plant parts showed better leavening performance compared to commercial strains.

The results of the present study indicated that the ability of the potent yeast isolates is comparable or even better than the commercial yeast in leavening of bread dough. Similarly, Ma'aruf et al., (2011) have indicated that yeast strains isolated from fruits showed higher leavening activity than that of the commercial yeast strain. Zaky and Nasr (2011) have compared the dough rising power of different brands of baker's yeasts (from Turkey, China, UK, and Egypt) sold in Egypt and all the yeast strains had maximum leavening activity after 2 hours of fermentation, but the highest leavening activity showed by the potent yeast isolates between 1 to 2 hours in the current study. This reveals that the leavening activity of indigenous yeast isolates showed shorter time of fermentation than that of the commercial baker's yeast making the potent yeast isolates of this study a potential candidate to be developed into commercial bakery yeast strains after further necessary tests.

A combination of the three isolates (AAUTf1 + AAUTf5 + AAUTj15) produced the highest leavening activity compared to single inoculations. Better performance of combined wild yeast isolates (this study) could be due to synergetic contribution of the isolates to the dough leavening action as demonstrated by several investigators (ClementeJimenez et al., 2005; Moreira et al., 2008; Domizio et al., 2011; Crafack et al., 2013; Saerens et al., 2013; Steensels et al., 2014), who reported that a combination of yeasts (non Saccharomyces cerevisiae + Saccharomyces cerevisiae ) is important for quality bread leavening and baking purpose. Both isolates of AAUTf1 (Candida humilis) and AAUTf5 (Kazachistania bulderi) of this study are uncommon types of yeasts in baking industries, but they have good leavening ability and aroma than of the commercial yeast (S.cerevisiae). Emphasizing the importance of uncommon yeast strains, Wedral et al., (2010) have demonstrated that many uncommon (non-conventional) types of yeasts are used in baking industries that have the ability to produce unique aroma compounds that $S$. cerevisiae lacks.

Overall, it was noticed that the combinations (AAUTf5 + AAUTj15) and (AAUTf1 + AAUTj15 + AAUSh17) of indigenous yeasts isolated from local substrates showed the highest leavening ability of bread indicating the possibility of developing indigenous baker's yeasts for large scale production. Thus, this can potentially increase the varieties of yeasts and ultimately decrease their importation at huge amount of foreign currencies.

Furthermore, this study may even lead to eventual screening of more indigenous potent yeast blends for local consumption and beyond after conducting various qualifying tests.

\section{Conclusions}

The results of our study demonstrated that fermented foods and drinks harbor potent baker's yeasts which can be used as dough leavening agents. The optimum growth conditions for yeasts to be used in large scale production are $30^{\circ} \mathrm{C}$ temperature, $5.5 \mathrm{pH}$ and 48 hours of incubation. The yeast isolate Saccharomyces cerevisiae exhibited good leavening activity and Candida humilis and Kazchistania bulderi (strains not used before for leavening bread dough) have better capacity of leavening and is concluded to be the most active yeasts to ferment bread dough compared to other strains including commercial yeast strain. Combinations of isolates (mixed culture) with Saccharomyces cerevisiae showed higher capacity of wheat dough leavening than the indigenous single isolates (monoculture) and of commercial yeast. Thus, the indigenous isolates are potential candidates that need fast promotion and utilization in bakery industries. Based on the findings of this study it is recommended that further investigation should be undertaken on organoleptic properties and other baker's yeasts qualifying parameters in order to enhance their desirability and efficiency of the screened strains.

\section{Acknowledgments}

The authors would like to thank Department of Microbial Cellular and Molecular Biology, Addis Ababa University, Molecular Research Center Advanced Laboratory, Addis Ababa, Ethiopia and other members of Brown University, USA for their kind collaboration in providing laboratory and DNA sequencing facilities. We are also thankful of the Ethiopian Ministry of Science and Technology for the financial support to conduct the research work herein.

\section{Conflict of interest}

Authors declare that there are no conflicts of interest in the study.

\section{References}

1. Arias, C.R., Burns, J.K., Friedrich, L.M., Goodrich, R.M., Parish, M.E. (2002). Yeast species associated with orange juice: Evaluation of different identification methods. Appl. Env. Microbiol. 68: 1955-1961.

2. Ashenafi, M. (2006). The microbiology of Ethiopian foods and beverages: A review. Ethiop J. Biol. Sci. 5: 189-245. 
3. Aslankoohi, E., Herrera-Malaver, B., Rezaei, M.N., Steensels, J., Courtin, C.M., Verstrepen, K.J. (2016). Nonconventional yeast strains increase the aroma complexity of bread. PloS One 11, e0165126.

4. Birch, A.N., Petersen, M.A., Hansen, A.S. (2013). The aroma profile of wheat bread crumb influenced by yeast concentration and fermentation temperature. Food Sci. Technol. 50: 480-488.

5. Ceccato-Antonini, S.R., Tosta, C.D., Silva, A.C. (2004) Determination of yeast killer activity in fermenting sugarcane juice using selected ethanolmaking strains. Brazil Arch. Boil. Technol. 47: 17-39.

6. Cho, I.H., Peterson, D.G. (2010). Chemistry of bread aroma: a review. Food Sci. Biotechnol. 19: 575-582.

7. Clemente-Jimenez, J.M., Mingorance-Cazorla, L., MartinezRodriguez, S., Heras-Vazquez, F.J.L., Rodriguez-Vico, F. (2005). Influence of sequential yeast mixtures on wine fermentation. Int. J. Food Microbiol. 98: 301-308.

8. Crafack, M., Mikkelsen, M.B., Saerens, S., Knudsen, M., Blennow, A., Lowor, S. (2013). Influencing cocoa flavour using Pichia kluyveri and Kluyveromyces marxianus in a defined mixed starter culture for cocoa fermentation. Int. J. Food Microbiol. 167: 103-116.

9. Domizio, P., Romani, C., Lencioni, L., Comitini, F., Gobbi, M., Mannazzu, I. (2011). Outlining a future for nonSaccharomyces yeasts: Selection of putative spoilage wine strains to be used in association with Saccharomyces cerevisiae for grape juice fermentation. Int. J. Food Microbiol. 147: 170-80.

10. Donalies, U.E., Nguyen, H.T.T., Stahl, U., Nevoigt, E. (2008). Improvement of Saccharomyces yeast strains used in brewing, wine making and baking. Adv. Biochem. Eng. Biotechnol. 111:67-98.

11. Edwards, W.P. (2007). The Science of Bakery Products. Royal Society of Chemistry, Cambridge.

12. Fellers, C.R., Shostrom, O.E., Clark, E.D. (1924). Hydrogen sulfide determination in bacterial cultures and in certain canned foods. J. bacterial. 9: 235-249.

13. Godfray, H.C.J., Beddington, J.R., Crute, I.R., Haddad, L., Lawrence, D., Muir, J.F. (2010). Food security: the challenge of feeding 9 billion people. Sci. 327: 812-818.

14. Hamelman, J. (2004). Bread: A Baker's Book of Techniques and Recipes. John Wiley, New York.

15. Jiranek, V., Langridge, P., Henschke, P.A. (1995). Validation of bismuth containing indicator media for predicting $\mathrm{H}_{2} \mathrm{~S}$ producing potential of Saccharomyces cerevisiae wine yeast under enological conditions. Am. J. Enol. Vitic. 46: 269-273.

16. Ma'aruf, A.G., Noroul, A.Z., Sakilah, A.M., Mohd, K.A. (2011). Leavening ability of yeast isolated from different local fruits in bakery product. Sains Malaysiana 40: 14131419.

17. Mamun-Or-Rashid, A.N., Dash, B.K., Chowdhury, M.N., Waheed, M.F., Pramanik, M.K. (2013). Exploration of potential baker's yeast from sugarcane juice: 623.

optimization and evaluation. Pak.J. Biol. Sci. 16: 617

18. Milkessa, T., Abate, D. (2014). Evaluation of Yeast Biomass Production using Molasses and Supplements. LAP LAMBERT Academic Publishing, Germany.

19. Moreira, N., Mendes, F., de Pinho, R.G., Hogg, T, Vasconcelos, I. (2008). Heavy sulphur compounds, higher alcohols and esters production profile of Hanseniaspora uvarum and Hanseniaspora guilliermondii grown as pure and mixed cultures in grape must. Int. J. Food Microbiol. 124: 231-8.

20. Nitayavardhana, S., Shrestha, P., Rasmussen, M.L., Lamsal, B.P., van Leeuwen, J.H., Khanal, S.K. (2010). Ultrasound improved ethanol fermentation from cassava chips in cassava-based ethanol plants. Bioresource technol. 101: 2741-2747.

21. Noroul, A., Ma'aruf, Z., Sahilah, A.G., Mohd, A.M., Khan, A., Wan Aida, W.M. (2013). A new source of Saccharomyces cerevisiae as a leavening agent in bread making. Int. Food Res. J. 20: 967-973.

22. Plessas, S., Pherson, L., Bekatorou, A., Nigam, P., Koutinas, A.A. (2005). Bread making using kefir grains as baker's yeast. Food chemis. 93:585-589.

23. Qureshi, S.K., Masud, T., Sammi, S. (2007). Isolation and taxonomic characterization of yeast strains on the basis of maltose utilization capacity for bread making. Int. J. Agri. Biol. 9: 110-113.

24. Saerens, S.M., Swiegers, H., Reynolds, D. (2013). Increasing the sensorial enrichment of white wine with nonSaccharomyces yeast strains. Australian and New Zealand Grapegrower and Winemaker, (599), p.94.

25. Savova, I., Nikolova, M. (2002). Isolation and taxonomic study of yeast strains from bulgarian dairy products. J. Cul. Collec. 3: 59-65.

26. Steensels, J., Snoek, T., Meersman, E., Nicolino, M.P., Voordeckers, K., Verstrepen, K.J. (2014). Improving industrial yeast strains: exploiting natural and artificial diversity. FEMS Microbiol. Rev. 38: 947-995.

27. Supanwong, K., Kazuyoshi, O., Shinsaku, H (1983). Environmental effects on ethanol tolerance of Zymomonas mobilis. J. Microbial. Utilization Renewable Resour., 3: 254-260.

28. Team R.C., (2016). R: A Language and Environment for Statistical Computing. $\mathrm{R}$ Foundation for statistical Computing, Vienna, Austria. URL https://www.Rproject.org/.

29. Wedral, D., Shewfelt, R., Frank, J. (2010). The challenge of Brettanomyces in wine. LWT Food Sci. and Technol., 43(): 1474-1479.

30. Zaky, A.S., Nasr, N.F. (2011). Easy and efficient method for measuring the rising power of baker's yeast. International Food Congress-Novel Approaches in Food Industry, pp 650654. 